\title{
Seroprevalence of Hepatitis A in Pediatric Age Groups in Bingöl Province
}

\author{
ilyas Duran' (1), Selçuk Nazik² (1) \\ ${ }^{1}$ Clinic of Medical Biochemistry, Bingöl Obstetrics and Pediatrics Hospital, Bingöl, Turkey \\ ${ }^{2}$ Clinic of Infectious Diseases and Clinical Microbiology, Bingöl Obstetrics and Pediatrics Hospital, Bingöl, Turkey
}

Cite this article as: Duran I, Nazik S. Seroprevalence of Hepatitis A in Pediatric Age Groups in Bingöl Province. JAREM 2018; 8: 15-8.

\begin{abstract}
Objective: Hepatitis Infection with hepatitis A virüs virus (HAV) infection is a common public health problem in our country and in the world. The prevalence of disease Prevalence of this disease, that which can be the a serious reason for morbidity and mortality reason, is closely related with socio-economic conditions and environmental factors. In this study, we aimed to investigate the seroprevalence of hepatitis A in pediatric age groups in Bingöl province.

Methods: In this study, we retrospectively evaluated the results of 4211 pediatric patients who requested HAV IgG and HAV IgM tests for various reasons and were admitted to our hospital between January 2010 and June 2016. Chi-square test was used to determine the statistical differences between categorical variables.

Results: The mean age of the patient ages in the this study was $8.9 \pm 5.8$ years (min-max: 0-18 years). Of all patients, $44.5 \%$ of the patients were male and $55.5 \%$ were female. The total HAV Ig G seropositivity rate was found to be $58 \%$. When The anti-HAV Ig G seropositivity rates were analyzed according to age groups, they were found to be $54.2 \%$ in patients aged below 2 years, 38.2\% in $2-6$ years, $49.6 \%$ in $7-10$ years, and $78.2 \%$ in 11-18 years. The total HAV Ig M seropositivity rate was found to be $11.6 \%$. When anti-HAV Ig M seropositivity rates were analyzed according to months, it was found to be higher in December (17.9\%) and November (17.1\%) and the least in May (4.6\%) and June (5.2\%).

Conclusion: It has been determined that the frequency of acute hepatitis A cases increases in December and November and that the seropositivity of hepatitis A Ig G increases with age after 2 years. In cases under below 2 years of age, the seropositivity of HAV Ig G is high and the seropositivity that of HAV Ig M is low, which is thought to be related to with vaccination and maternal antibodies.
\end{abstract}

Keywords: Child, hepatitis A, seroprevalence

ORCID IDs of the authors: i.D. 0000-0001-9269-6014; S.N. 0000-0003-0587-0104

\section{INTRODUCTION}

Hepatitis A virus (HAV), which is from the Picornaviridae family, is an envelope-free and single-stranded RNA virus with linear positive polarity. Its diameter is approximately $27-28 \mathrm{~nm}$. The most important reservoir of HAV is humankind. The virus is infected through the fecal-oral way from contaminated food and water. Because it is envelope-free, it is resistant to detergents, disinfectants, temperatures up to $60^{\circ} \mathrm{C}$, and external environment (1-4).

It is estimated that approximately 1.4 million people are infected with HAV per year all over the world (5). There are three different endemicity patterns: high, moderate, and low; these are categorized according to their rates of incidence in the world. The regions with high endemicity are developing countries where sanitization and hygienic applications are inadequate. Approximately $90 \%$ children in these regions are infected with HAV within the first 10 years of age. HAV has low endemicity in developed regions where sanitization and hygienic applications are suitable. In Turkey, which is in the moderate endemic region, HAV seroprevalence exhibits a wide range between the eastern and western parts of the country (8\%-88\%). Age, regional distribution, and socioeconomic status are attributed for this difference $(6,7)$.

HAV infection, which is an important public health problem in Turkey and in the world, is a disease that has a vaccination and can be prevented. The hepatitis A vaccine, which was first used in 1995, was observed to have a serious preventive effect on the formation and spread of the hepatitis clinic (8). This vaccine-administered in two doses at the end of the $18^{\text {th }}$ and $24^{\text {th }}$ monthsentered into the routine vaccination calendar in Turkey in September 2012 (9).

In this study, it was aimed to evaluate the seroprevalence of the $\mathrm{HAV}$ infection according to age groups, genders, and months in our region.

\section{METHODS}

The study consists of patients who were admitted to our hospital between January 2010 and June 2016. The results of a total of 19862 cases for whom anti-HAV IgG and anti-HAV IgM were requested were retrospectively evaluated, and 4211 cases at 18 
years of age and under were included in this study. The included cases were divided into four groups according to age ( $<2$ years; 2-6 years; 7-10 years; and 11-18 years) and examined. Ethics committee approval was obtained from the General Secretariat of Public Hospitals Association in Bingöl (June 10, 2016).

Approximately $10 \mathrm{cc}$ of blood samples from patients was centrifugated and the presence of hepatitis $A$ antibodies in the serum samples was investigated with the chemiluminescent microparticle immunoassay (CMIA) test (Roche, Cobas 6000, USA). Sam-

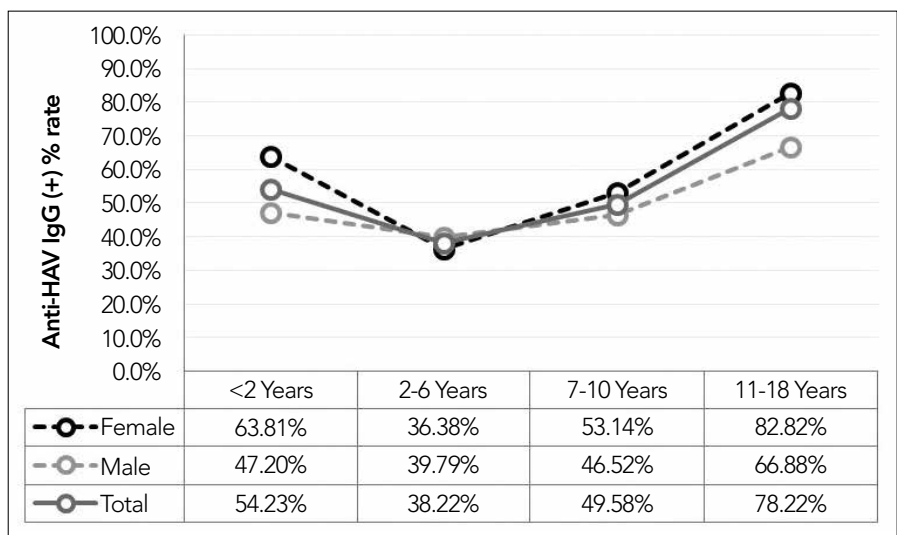

Figure 1. Distribution of Anti-HAV lgG seropositivity according to age groups and genders

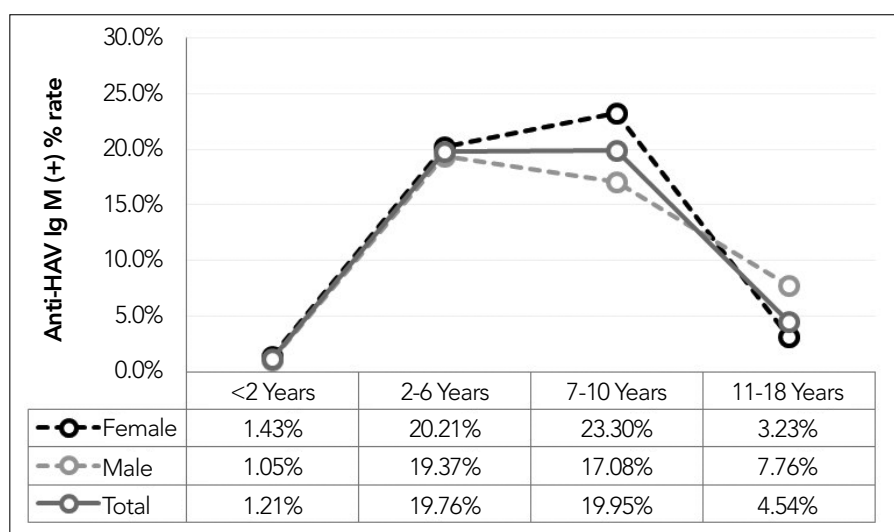

Figure 2. Distribution of Anti-HAV Ig M seropositivity according to age groups and genders

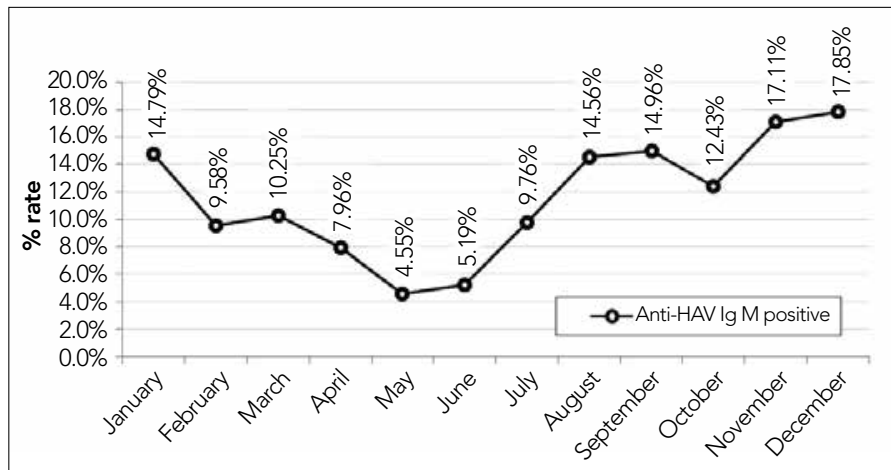

Figure 3. Distribution of anti-HAV Ig M seropositivity according to months ples with values below $1 \mathrm{~S} / \mathrm{CO}$ were evaluated as negative and samples with values $\geq 1 \mathrm{~S} / \mathrm{CO}$ were evaluated as positive, which was in accordance with the manufacturer's recommendations.

\section{Statistical Analysis}

Statistical evaluation of the data obtained in this study was performed using the SPSS version 17.0 package program (Statistical Package for the Social Sciences Inc.; Chicago, IL, USA). While continuous data were summarized as mean and standard deviation, categorical data were summarized as number and percentage. A chi-square $\left(\chi^{2}\right)$ test was used to assess two categorically independent groups for intergroup comparisons. The statistical significance level was set at $p<0.05$.

\section{RESULTS}

In this study, 4211 patients were included. Out of these patients, $44.5 \%(n=1874)$ were male and $55.5 \%(n=2337)$ were female. The mean age of the cases included in our study was $8.9 \pm 5.8$ years (minimum-maximum: 0-18 years).

The seropositivity of anti-HAV IgG in all the cases was determined to be $58 \%(n=2444)$. When gender distribution out of the cases with anti-HAV IgG (+) was examined, it was found that $62.1 \%$ cases were female $(n=1518)$ and $37.9 \%(n=926)$ were male. In females, the seropositivity of anti-HAV IgG was found to be statistically significantly higher than that of males $\left(\chi^{2} p=0.000\right)$. The distribution of anti-HAV IgG seropositivity according to age groups and gender is presented in Figure 1.

The incidence of acute hepatitis $A$ infection was observed as $10.5 \%(n=245)$ in females and as $13.1 \%(n=245)$ in males, and antiHAV IgM seropositivity was detected as $11.6 \%(n=490)$ in all the cases. When the seropositivity of anti-HAV IgM was compared according to gender, it was found to be statistically significantly higher in the male group than the female group $\left(\chi^{2} p=0.009\right)$. The distribution of anti-HAV IgM seropositivity according to age groups and gender is presented in Figure 2.

The distribution of anti-HAV IgM seropositive cases was analyzed according to months. It was found that the seropositivity rate of anti-HAV IgM was the highest in December (17.9\%, $\mathrm{n}=73$ ) and November $(17.1 \%, n=51)$, and it was the lowest in May $(4.6 \%$; $n=15)$ and June (5.2\%; $n=19)$. The distribution of anti-HAV IgM seropositivity according to months is presented in Figure 3.

\section{DISCUSSION}

The seroprevalence of the hepatitis $A$ infection varies in our country and in the world. Factors such as age, region, and socioeconomic level are among the most important reasons for this situation (10).

In the literature, it is seen that there are different results in studies in which gender and HAV IgG seropositivity are evaluated together. In the study by Iraz et al. (9), it was found that the seropositivity of HAV IgG in males was lower, but there was no statistically significant difference between the groups. In the studies conducted by Kurt et al. (11) and Demirpençe et al. (12), it was found that the seropositivity rate of HAV IgG was higher in males. It is believed that this high rate may be attributable to (1) in- 
creased contact with the outside environment and (2) consumption of food and beverages prepared under improper conditions. However, in many studies, there were no significant differences in the incidence of hepatitis A infections in terms of gender (13, 14). In this study, the seropositivity of HAV IgG was found to be significantly higher in females than in males $\left(\chi^{2} p=0.000\right)$.

In the study performed by Çetinkol and Yıldırım (15), it was found that the seropositivity of anti-HAV IgG in cases who were 0-23 months old was $50 \%$ in our country. In another study conducted by Aşçı et al. (16), it was found that the seropositivity of anti-HAV IgG between 0 and 2 years was $57.4 \%$. In another study conducted by Güven et al. (17), it was observed that the seropositivity of anti-HAV IgG was $57.4 \%$ for patients between 0 and 2 years of age. In this study, results similar to the data in the literature were obtained. In this age group, the most important cause for the increase in the hepatitis A IgG seropositivity is thought to be the effect of maternal protective antibodies. Low seropositivity of HAV IgM also supports this effect.

Considering the date of this study and the entering of the hepatitis $A$ vaccine into the routine vaccination schedule in our country (September 2012), there are two types of patients: (1) vaccinated patients and (2) patients who became immune because they had the disease in the age group of 2-6 years. The increase in social and environmental interactions of children in this age group and the completion of the effectiveness of maternal antibodies were important factors for us to specify this group. In a study conducted in Ordu before the routine vaccination of hepatitis A vaccine came into effect, the seropositivity of hepatitis $A$ IgG in 2-6-year-old cases was $29.2 \%$ (15). In another study conducted in our country, it was found that hepatitis A IgG seropositivity was $33.5 \%$ in the 2-6-year-old group (17). The seropositivity of hepatitis A IgG obtained in this study is $38.2 \%$, which is higher than the HAV IgG seropositivity values obtained in the literature.

There are many studies in the literature covering the ages of 7-18 years, but these studies were conducted in different age groups. As a common result of these studies, the seropositivity of hepatitis $A$ has been shown to increase with age. In the study conducted by Erdoğan et al. (18) in Edirne, the seroprevalence values of HAV IgG were determined to be $25,37.3$, and $43.2 \%$ in the age groups of 6-10,11-14, and 15-19, respectively. In a study performed by Türker et al. (19) in Ankara, the seropositivity values of HAV IgG were determined to be $20.9,29$, and $43.9 \%$ in the age groups of 5-9, 10-14, and 15-19, respectively. In a study conducted by Kaya et al. (20) in Kahramanmaraş in 2007, it was determined that the seropositivity values of HAV $\mathrm{lgG}$ in the age groups of 6-10 and $11-14$ were $74.3 \%$ and $83.0 \%$, respectively. Similar to the literature, the seropositivity of HAV IgG was found to increase with age in this study.

Further, the seropositivity rate of HAV IgM-a marker of acute hepatitis A-was found to be low in the age group of 0-2 years in this study. This is due to the reduction in the risk of hepatitis A infection with the protective effect of maternal IgG antibodies until two years of age $(17,21)$. As a result of the increase in social and environmental interactions during pre-school (2-6 years) and primary school (7-10 years), it is seen that there is a significant in- crease in HAV IgM seropositivity. It is thought that the reason for the decrease in the HAV IgM positivity rate during adolescence (11-18 years) is related to the early experience of the disease. The HAV IgM positivity rate during childhood was examined in a study conducted by Parlak et al. (22) in Van. The HAV IgM positivity rate was found to be $9.8 \%$ in all the children. There was no significant difference between gender and HAV IgM positivity in the same study $(p=0.665)$. In another study conducted in Igdır, it was found that the seropositivity of anti-HAV IgM was $18.1 \%$ in 0-18 years (23). In other studies where the rate of HAV IgM seropositivity in childhood was investigated in our country, these rates were seen to be $15.1 \%$ (24) and $12 \%$ (25). In this study, it was seen that the HAV IgM seropositivity value during childhood was similar to that in the literature. However, HAV IgM seropositivity was found to be higher in males than in females $\left(\chi^{2} p=0.009\right)$.

The hepatitis A infection is an important public health problem for seronegative individuals, particularly in the pediatric age group. In autumn and winter, the hepatitis A infection is more prevalent, which can be attributed to rising rainfall. The average incubation period of $\mathrm{HAV}$, which increases in the summer months in an appropriate environment, is 28 days (5-50 days) (26). In the study conducted by Parlak et al. (22), it was found that the rates of acute hepatitis A started to increase in August and reached the highest level in November and December. Results similar to the data in the literature were obtained in this study, too. Inadequate drainage of increasing rainwater and inadequate sewerage and infrastructure systems are thought to be important reasons for this effect.

\section{CONCLUSION}

It was observed that the incidence of acute hepatitis A was higher in the male gender in our study, and it increased in December and November. In addition, hepatitis A IgG seropositivity was found to increase with age after 2 years. In patients under 2 years of age, the seropositivity of HAV IgG was high and the seropositivity of HAV IgM was low, which was thought to be related to vaccination and the presence of maternal antibodies.

Ethics Committee Approval: Ethics committee approval was received for this study from the ethics committee of Bingöl Association of Public Hospitals.

Informed Consent: Due to the retrospective design of the study, informed consent was not taken.

Peer-review: Externally peer-reviewed.

Author Contributions: Concept - I.D., S.N.; Design - I.D., S.N.; Supervision - i.D., S.N.; Resources - I.D., S.N.; Materials - i.D., S.N.; Data Collection and/or Processing - I.D., S.N.; Analysis and/or Interpretation - I.D., S.N.; Literature Search - I.D., S.N.; Writing Manuscript - I.D., S.N.; Critical Review - I.D., S.N.

Conflict of Interest: No conflict of interest was declared by the authors.

Financial Disclosure: The authors declared that this study has received no financial support.

\section{REFERENCES}

1. Anderson DA. Hepatit A ve E virusları. In Murray PR, Baron EJ, Jorgensen JH, Landry ML, Pfaller MA, eds. Manuel of Clinical Microbiology. DC: ASM press, 2009; 1424-36. 
2. Topçu AW, Söyletir G, Doğanay M. Infeksiyon hastalıkları ve mikrobiyolojisi, 1.baskı, Nobel Tıp Kitabevleri, İstanbul 2002: 1340-50.

3. Özen M, Yoloğlu S, IşıkY, Tekerekoğlu MS. Turgut Özal Tıp Merkezi'ne başvuran 2-16 yaş grubundaki çocuklarda Anti-HAV IgG seropozitifliği. Turk Pediatri Ars 2006; 41: 36-40.

4. Mıstık R. Viral Hepatitler. Ed. Altındiş M. Hemşireler İçin Mikrobiyoloji. İstanbul, Nobel Tip Kitapevleri, 2010; 268-9.

5. Available from: http://www.who.int/immunization/diseases/hepatitisA/en/ (Son erişim tarihi:10/04/2017).

6. Jacobsen $\mathrm{KH}$, Wiersma ST. Hepatitis A virus seroprevalence by age and world region, 1990 and 2005. Vaccine 2010; 28: 6653-7. [CrossRef]

7. Yoldaş Ö, Bulut A, Altındiş M. Hepatit A Enfeksiyonlarına Güncel Yaklaşım. Viral Hepat J 2012; 18: 81-6. [CrossRef]

8. Song HJ, Kim TH, Song JH, Oh HJ, Ryu KH, Yeom HJ, et al. Emerging need for vaccination against hepatitis $A$ virus in patients with chronic liver disease in Korea. J Korean Med Sci 2007; 22: 218-22. [CrossRef]

9. Iraz M, Gültepe B, Doymaz MZ. Erişkin Yaş Gruplarında Hepatit A Seroprevalansı. Abant Med J 2015; 4: 54-8. [CrossRef]

10. Bozkaya E. Virusların sınıflandırılması, Temel ve klinik Mikrobiyoloji, Editör: Şemsettin Ustaçelebi, Güneş Güneş Kitabevi, Ankara 1999: 749-54.

11. Kurt H, Battal I, Memikoğlu O, Yeşilkaya A, Tekeli E. Ankara bölgesinde sağlıklı bireylerde HAV, HBV, HCV seropozitifliğinin yaş ve cinsiyete göre dağılımı. Viral Hepatit Dergisi 2003; 8: 88-96.

12. Demirpençe Ö, Işık Tezcan S, Değirmen E, Çelen MK. Batman Devlet Hastanesine Başvuran Kişilerde Hepatit ve HIV Serolojisinin Sonuçları. Viral Hepatit Dergisi 2012; 18: 6-10. [CrossRef]

13. Ertürk A, Çopur Çiçek $A$, Cüre E, Öztürk Ç. Rize ilinde erişkin yaş gruplarında Hepatit A seroprevalansı. Viral Hepatit Dergisi 2013; 19: 85-8. [CrossRef]

14. Özkinay F, Kurugöl Z, Koturoğlu G, Özacar T, Altuğlu I, Vardar F, et al. The epidemiology of Hepatitis $A$ infection in the population of Bornova, İmir, Turkey. Ege Tıp Dergisi 2007; 46: 1-6.
15. Çetinkol Y, Yıldırım AA. Ünye Devlet Hastanesine Başvuran Hastalarda Hepatit A Seroprevalansı. Kocatepe Tıp Dergisi 2011; 12: 18-22.

16. Aşcı Z, Akgün S, Keşli R. Afyonkarahisar ilinde farklı yaş gruplarında Hepatit A seroprevalansı. Göztepe Tıp Dergisi 2014; 29: 94-8.

17. Güven F, Erkum Ay, Erkum T. 0-15 Yaş Arası Çocuklarda Hepatit A Seroprevalansı. Zeynep Kamil Tıp Bülteni 2014; 1: 41-4.

18. Erdoğan MS, Otkun M, Tatman-Otkun M, et al. The epidemiology of hepatitis a virus infection in children, in Edirne, Turkey. Eur J Epidemiol 2004; 19: 267-73.

19. Türker K, Balcı E, Batı S, Hasçuhadar M, Savaş E. Ülkemizde hepatit A enfeksiyonunun değişen epidemiyolojisi. Türk Mikrobiyol Cem Derg 2011; 41: 143-8.

20. Kaya D, Guler E, Ekerbicer HC, Dilber C, Karabiber H, Guler S, et al. Hepatitis A seroprevalence and its relationship with environmental factors in children of different age groups in Kahramanmaras, Eastern Mediter-ranean region of Turkey. J Viral Hepat 2007; 14: 830-4.

21. Yoldaş Ö, Bulut A, Altındiş M. Hepatit A Enfeksiyonlarına Güncel Yaklaşım. Viral Hepatit Dergisi 2012; 18: 81-6. [CrossRef]

22. Parlak M, Çıkman A, Güdücüoğlu H. Türkiye'nin Van yöresinde Anti HAV IgM pozitifliğinin yaş ve aylara göre dağılımı. Dicle Med J 2012; 39: 398-402. [CrossRef]

23. Arvas $G$, Kaya B, Berktaş M. Iğdır Devlet Hastanesi'ne başvuran 0-18 yaş grubu çocuklarda akut Hepatit A seroprevalansı. J Pediatr Inf 2011; 5: 129-31. [CrossRef]

24. Okur M, Erbey F, Acar MN. Van ili ve çevresinde 0-18 yaşları arasındaki çocuklarda hepatit a seropozitifliği. Düzce Tıp Dergisi 2011; 13: 6-9.

25. Arabacı F, Oldacay M. Çanakkale yöresinde çeşitli yaş gruplarında Hepatit A seroprevalansı ve akut hepatitli olgularda Hepatit A sıklığı. J Pediatr Inf 2009; 3: 58-61.

26. Badur S. Viral hepatitler (HAV, HBV, HDV) In: Ustaçelebi Ş, Abacıoğlu H, Badur S (eds). Moleküler, Klinik ve Tanısal Viroloji, Ankara; Güneş Kitabevi 2004: 175-202. 